University of Nebraska - Lincoln

DigitalCommons@University of Nebraska - Lincoln

Virology Papers

Virology, Nebraska Center for

July 1976

\title{
Simplified Method for Efficient Intravascular Inoculation of Chicken Embryos
}

Clayton L. Kelling

University of Nebraska-Lincoln, ckelling1@Unl.edu

I. A. Schipper

North Dakota State University, Fargo

Follow this and additional works at: https://digitalcommons.unl.edu/virologypub

Part of the Virology Commons

Kelling, Clayton L. and Schipper, I. A., "Simplified Method for Efficient Intravascular Inoculation of Chicken Embryos" (1976). Virology Papers. 108.

https://digitalcommons.unl.edu/virologypub/108

This Article is brought to you for free and open access by the Virology, Nebraska Center for at DigitalCommons@University of Nebraska - Lincoln. It has been accepted for inclusion in Virology Papers by an authorized administrator of DigitalCommons@University of Nebraska - Lincoln. 


\title{
Simplified Method for Efficient Intravascular Inoculation of Chicken Embryos
}

\author{
C. L. KELLING* AND I. A. SCHIPPER \\ Department of Veterinary Science, North Dakota State University, Fargo, North Dakota 58102
}

Received for publication 6 April 1976

The simple syringe-stabilizer unit described in this note provides a means for rapid intravascular inoculation of embryonated chicken eggs with minimal embryonic death from vascular trauma.

Intravascular inoculation of chicken embryos is an efficient means of cultivation of certain viruses. Goldsmit and Barzilai (4) reported that a thousand times greater amount of bluetongue virus was needed when the yolk sac inoculation method was used than when the intravenous method was employed. The same workers (5) later reported that bluetongue virus could be isolated from sheep blood with a saving of 6 weeks when the intravenous technique was used. Later, intravascular inoculation of embryonated chicken eggs was found to be equivalent to sheep inoculation for isolation of bluetongue virus from sheep blood (3).

Traditional methods of intravascular inoculation of chicken embryos have been laborious and usually result in high embryonic mortality from vascular trauma (2). Improved methods require elaborate and costly instrumentation $(2,6)$ or two operators (2). The syringe-stabilizer unit described herein can be easily assembled from items readily available to all laboratories at minimal cost. An operator working alone using this unit can efficiently inoculate embryonated eggs with minimal vascular trauma.

Fabrication procedure. The syringe-stabilizer was assembled by mounting a 50 -ml glass syringe in an inverted position on a ring stand at a $30^{\circ}$ angle using two three-prong grip clamps (Fig. 1). Two wooden clothespins were taped to the glass syringe plunger. The clothes-

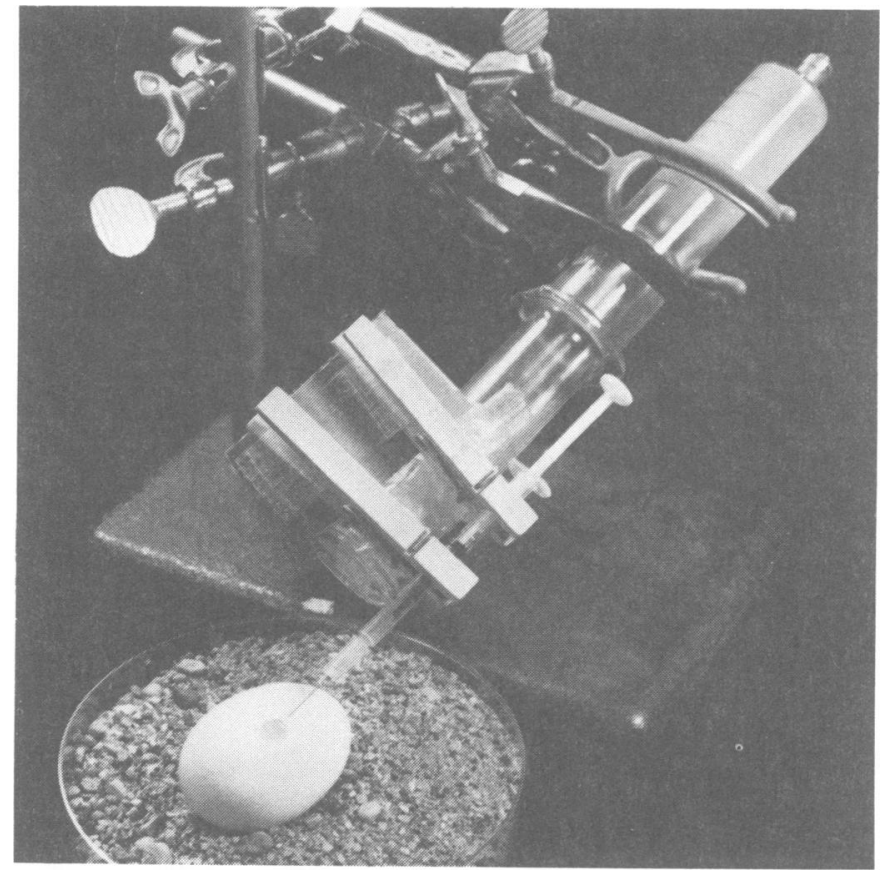

Fig. 1. Easily constructed syringe-stabilizer that simplifies the intravascular inoculation of embryonated chicken eggs. 
pins were used to clamp a $1.0-\mathrm{ml}$ tuberculin syringe with a 0.5 -inch (ca. $1.3 \mathrm{~cm}$ ), 27 -gauge needle for the intravenous inoculation. A piece of cardboard ( 4 by $7 \mathrm{~cm}$ ) was taped to the clothespins to facilitate their operation. Silicone lubricant was applied to the glass syringe plunger to prevent slippage.

Operation. Embryonic veins were located and marked with the aid of an egg candler (Speed King, The Speed King Co., Chicago, Ill.). Round windows $(0.5 \mathrm{~cm})$ were cut through the egg shells by using a diamond-impregnated, straight handpiece, shank, invertedcone dental instrument (model KC-1B, Densco, Incorporated, Denver, Colo.) (7). A drop of mineral oil was used to produce a translucent membrane to reveal the vein to be used for inoculation. The egg was stabilized on washed gravel in a petri dish (6) and was positioned under the stabilized tuberculin syringe, which contained the inoculum. The inoculation site was illuminated with a brilliant light source. The tuberculin syringe was positioned laterally by sliding the glass syringe plunger in or out and was positioned vertically by rotating the glass sy- ringe plunger in the syringe barrel. The silicone lubricant on the glass syringe plunger held the tuberculin syringe in stationery position after penetration of the vein and while the inoculum $(0.2 \mathrm{ml})$ was delivered. Use of a bench-type, illuminated magnifier lamp facilitated venipuncture and minimized eye strain.

\section{LITERATURE CITED}

1. Eichhorn, E. A. 1940. A technique for the intravenous inoculation of chick embryos. Science 92:245-246.

2. Foster, N. M., and A. J. Luedke. 1968. Direct assay for bluetongue virus by intravascular inoculation of em. bryonating chick eggs. Am. J. Vet. Res. 29:749-753.

3. Foster, N. M., and A. J. Luedke. 1972. Bluetongue in sheep and cattle: efficacy of embryonating chicken eggs in viral isolation. Am. J. Vet. Res. 33:77-81.

4. Goldsmit, L., and E. Barzilai. 1965. Isolation and propagation of a bluetongue virus strain in embryonating chicken eggs by the intravenous route of inoculation-preliminary report. Refu. Vet. 22:279-285.

5. Goldsmit, L., and E. Barzilai. 1968. An improved method for the isolation and identification of bluetongue virus by intravenous inoculation of embryonating chicken eggs. J. Comp. Pathol. 78:477-487.

6. Goldwasser, R., and M. C. Shelesnyak. 1953. A syringe carrier and egg clamps for intravenous inoculation of chick embryos. Science 118:47-48.

7. Luedke, A. J., and E. I. Anakwenze. 1972. Bluetongue virus in goats. Am. J. Vet. Res. 33:1739-1745. 